\title{
Agreement of Land Control by Foreign Citizens with Indonesian Citizens that are Potential for Disposal
}

\author{
Ni Komang Arini Styawati ${ }^{1}$, I Nyoman Sumardika ${ }^{2}$, I Made Minggu Widyantara ${ }^{3}$ \\ \{arinistyawati@gmail.com¹, istayuan@yahoo.co.id ${ }^{2}$ \} \\ Faculty of Law Universitas Warmadewa Denpasar-Bali, Indonesia ${ }^{123}$
}

\begin{abstract}
This study examines the problem of the form of agreement made by foreigners with Indonesian citizens as an instrument to exercise control of land rights in the face of the inheritance and forms of land ownership by foreigners who have the potential to cause disputes. The results showed that the agreements made by foreigners with Indonesian citizens to control the land before a notary in the form of deeds: Rent Land Leasing, Preliminary Agreement Provision of HGB for Ownership Land, Power of Attorney, HGB Renewal Agreement on Ownership Land, Preliminary Agreement on Land Use Rights Property Rights, Renewal Agreement for Right to Use on Ownership Rights, Recognition of Debt with Guarantees, Statement and Authorization, Power of Use and Establishment of Building, Renting Power of Attorney, Granting of Mortgage Rights, Selling Authorization, Power of Attorney, and Extension of Leasing. The form of land tenure by foreigners that has the potential to cause disputes is the occurrence of pseudo ownership with the character of "Ownership Rights Plus" because foreigners can control land more than the nature of property rights, which is immune from the law and not abolished due to the social function of the land.
\end{abstract}

Keywords: Land Tenure, Foreign Citizens.

\section{Introduction}

The form of legal actions and forms of land tenure, which are carried out by foreign nationals, are now widely suspected of being legal smuggling which has the potential to cause disputes. Maria SW Sumardjono [2], in this connection states that the transfer of ownership rights is disguised by surrendering ownership rights to foreign nationals with rent for buildings or with use rights, an absolute power of attorney to foreign citizens to do all legal acts relating to a land title held by Indonesian citizens at the expense of a foreign citizen which are some form of legal smuggling. This condition is prone to cause disputes because it is inseparable from the principle of nationality which underlies the Government's policy in the field of land as stipulated in Article 9 of the BAL. This means that the LoGA only allows Indonesian citizens to have a full relationship with earth, water and space. The meaning of Article 9 paragraph (1) as such has caused a distinction between Indonesian citizens and foreign citizens in the field of control and ownership of land rights. At the practical level Foreign Citizens tend to choose agreement instruments to bind Indonesian Citizens by utilizing Notary legal services. The notary through the deed he made has great potential in terms of the occurrence of land control by foreign citizens by including Indonesian citizens. Formally the position of Indonesian Citizens in the deed made is as land owner even though the nature of ownership is 
false or not true. From the initial identification, information is obtained that, the Notary is willing to make the relevant deed with argumentation because the deed made is the deed of the party, and the principle of freedom of contract as stipulated in Book III KUH. Civil. Furthermore, regarding the results of the initial inventory of the types of deeds made before a Notary by Foreign Citizens with the intention of binding Indonesian Citizens, among others, through legal instruments in the form of deeds (a) power of sale, (c) land rent, (d) extension of lease, (e) debt recognition, (f) statement, (g) power of attorney. This means the issue of legal relations between overseas academician; Indonesian citizens becomes an interesting and important thing to study. There are 2 (two) problems that will be studied in this study, namely: (1) what forms of agreement are carried out by foreign nationals to bind Indonesian citizens in the field of land control before a Notary? and (2) how is the form of land ownership by foreign citizens that have the potential to cause disputes?

\section{Methodology}

This research is a normative research and is supported by the results of field research at the Notary Office in the Province of Bali, Officials at the Land Office who have the authority in the field of registration / elimination of mortgage rights. In line with the opinion of Sudikno Mertokusumo, the objective of this study is the norm in the form of law (das Sollen) for library research and behavior (das Sein) for its field research [1]. The sample in this study was determined by a non-random sampling technique, namely purposive sampling. The collection of primary data is done through interviews and the collection of secondary legal materials is done by library research. The analysis uses systematic interpretation methods with a mindset that is collapsed and coherent to get conclusions on the two problems discussed in this study.

\section{Result and Discussion}

Forms of agreements carried out by foreign nationals to bind Indonesian citizens in the area of the ruler of the land to the Secretary There are two categories of agreements made by foreign nationals to bind Indonesian citizens in the field of land tenure, which is carried out by subordinate deed and authentic deed. The form of legal action with a one-sided subordinate deed in the control of land by a foreign citizen is carried out with a statement made under the hands of Indonesian citizens, and a two-handed subordinate deed carried out by foreign citizens in land control by means of an agreement Borrow Names (nominees). Regarding the forms of Notarial Deeds which are used as legal instruments of foreign citizens' rights to land ownership are quite varied with the following findings:

1) Power of Attorney and Guaranteed Debt Deed.

2) The Deed of Power of Use and Establishing Buildings and Renting Authority Deeds.

3) Deed of Statement and Power of Attorney, Deed of Giving Mortgage Rights, and Deed of Selling Authorization.

4) Deed of Renewal Right to Ownership of Land Ownership Agreement, Deed of Preliminary Agreement for Granting Right to Ownership Land, Deed of Right of Use Agreement for Land Ownership, Roya Power of Attorney, and Deed of Lease Extension

Furthermore, there are several alternatives that can be done to strengthen land tenure by foreign citizens, namely: First, by making Debt Recognition Deed with Guarantees, Statement 
of Deed and Power of Attorney, Deed of Power of Use and Building, Deed of Renting Power of Attorney, and Deed of Giving Rights, Second, by making the Preliminary Agreement Deed of Guna Building Rights, Power of Attorney, Deed of Land Use Rights Renewal Agreement, Preliminary Agreement Deed of Giving Right to Ownership Land, and Deed of Agreement to Renew the Right to Use on Owned Land, Third, by making Power of Attorney, Debt Recognition Deed with Assurance, Power of Use Deed and Building, Deed of Renting Power of Attorney, and Fourth Deed of Giving Rights, by making Power of Attorney, Guaranteed Debt Deed, Power of Use Deed and Building Establishment, Deed of Renting Power of Attorney, and Deed of Selling Authority. In relation to legal instruments in the form of a deed under the hand made with a Statement Letter and Loan Name Agreement. Land tenure legal instruments made by more foreign citizens are pragmatically oriented in the form of business interests, prioritizing the principle of trust in Indonesian citizens, reflecting the principle of freedom of contract which essentially constitutes broad freedom, ignoring the principle of good faith and the position of Indonesian citizens in the position is unbalanced even though formally the person concerned is the holder of the land rights but materially the Foreign Citizen can carry out legal actions to the widest extent of the land under his control.

\subsection{Forms of Land Tenure by Foreign Citizens that have the potential to cause disputes}

In the practice level, the characteristics of land tenure by foreign citizens who indicate legal smuggling and the potential to cause disputes can essentially be grouped as follows:

1) Land control by using a loan / nominee agreement. This form is chosen by a land ownership model that uses a method of buying and selling on behalf of an Indonesian citizen with a source of money from a foreign citizen. Furthermore, accompanied by the making of an agreement between Indonesian citizens and foreign citizens by means of power of attorney absolute, which gives rights that cannot be withdrawn by the authorizer (Indonesian Citizen) and authorizes the recipient of the power of attorney (Foreign Citizens) to carry out all legal acts relating to the land rights, which according to the law should only be carried out by the rights holder (Indonesian Citizens), so that a power of attorney like this fulfills the character of transferring land rights.

2) Land tenure based on leasing, with unreasonable rental prices, foreign nationals domiciled in Indonesia may also be subject to lease rights for buildings, but the granting of lease rights has the potential to become a covert transfer of ownership, which is a practice of legal smuggling. potential to cause a dispute. As an indication of the existence of legal smuggling which is substantively a covert transfer, for example things can happen as follows:

a. Rent is paid at once or substitute money to surrender the use rights of approximately the same as the price of the land;

b. The period of the agreement (rent) exceeds the limit of reasonableness;

c. The owner can only ask for his land back by paying back the actual land price [3] The aforementioned matter shows that materially there has actually been a covert transfer of Property Rights, this is a form of legal smuggling.

3) Land ownership with the mode of granting mortgage rights by foreign citizens. Granting of Mortgage Rights with creditors of Foreign Citizens which has the potential to be a transfer of rights to land (ownership rights) covertly. In relation to land tenure by foreigners, the Underwriting Right instrument is used in practice with the formula for the agreement of the pretended debt, which is packaged in the form of Guaranteed Debt Deed. Furthermore, 
the Debt Recognition Deed with the Guarantee is attached to the imposition of Underwriting Rights with its creditor Foreign Citizen. The indication of the transfer of covert property rights can be seen from 2 (two) categories, namely:

a. Debt agreement which is the basis for the imposition of Underwriting Rights is an agreement on debt of pretended debt made before a Notary in the form of Debt Recognition Deed with Guarantee

b. Value of Underwriting Rights equal to the price of the land.

4) In addition, covert forms of land control by foreign citizens are ownership of land by mixed marriages between Indonesian citizens and foreign citizens who do not have marriage agreements, especially regarding the separation of property, where an Indonesian citizen who marries a foreign citizen buys a piece of land ownership, which is generally a source of funds from foreign citizens, but they do not bring up their marriage identity, so that the formal juridical does not violate the rules, but substantially there has been land ownership (Hak Milik) by couples with dual citizenship which of course has not fulfilled the requirements as the subject of Property Rights.

Normatively all forms of land control carried out by foreigners with the instrument of agreement / power of attorney fulfill the character of the transfer of rights (ownership rights) to foreign citizens covertly. The legal consequences are agreements / power of attorney made invalid and null and void because they violate the provisions of article 26 paragraph (2) of the LoGA substantially. Based on the discussion of examples of deeds that have been carried out, it can be seen that the deeds made relating to the control of land by foreign citizens are more beneficial and strengthen the position of foreign citizens. The rights of foreign citizens who are recognized and affirmed in the above deed are very tendentious and even exceed the rights recognized in property rights. In other words, through a Notary deed instrument, foreign nationals can have land rights with the character of "Property Rights Plus". Having equality with property rights can be observed from the character of ownership rights found in the Notary deed relating to the control of land by foreign citizens, namely:

a. Recognition of a hereditary nature means that land tenure does not only last for the life of a foreign citizen who controls it, but can be continued by his heirs if all the owner dies;

b. The strongest nature indicated by the period of unlimited control of land is supported by proof of rights in the form of a Notary deed;

c. Having a full nature that gives very wide rights to foreign citizens in utilizing land that is controlled, including also being able to make it as the parent of other rights, such as can be used as collateral for debt by being burdened with mortgage rights, can be transferred, such as being sold, exchanged for other objects, granted, and given with a will. Meanwhile, the meaning of "Plus" in the context of "Property Rights Plus" is found in the granting of legal immunity through a Notary deed in land ownership by Foreign Citizens, both against legal changes that are deemed detrimental to Foreign Citizens and to restrictions on social functions imposed on land rights stipulated in the LoGA. 


\section{Conclusion}

Regarding the form of legal action carried out by foreign nationals to bind Indonesian citizens to control the land that has the potential to cause disputes, namely by the Notary deed in the form of Land Renting Deed, Preliminary Agreement Deed of Guna Building Rights, Proxy Deed, Agreement Renewal of Building Use Rights on Property Rights, Preliminary Agreement Deed for Right of Use on Ownership Land, Deed of Right to Use Rights Agreement, Debt Recognition Deed, Statement of Deed and Power, Deed of Use and Establish Building, Power of Attorney Renting, Deed of Giving Rights, Deed of Selling Authorization, Roya Power of Attorney, and Deed of Lease Rental Extension; Concerning land tenure by foreigners that has the potential to cause disputes that indicate legal smuggling in the form of simulation actions carried out by foreign nationals in controlling land by using an agreement instrument that seems not to violate applicable laws because it is not in the form of transfer of rights directly. Furthermore, it relates to the form of land tenure by foreign nationals that has the potential to cause disputes because of the apparent ownership of "Property Rights Plus" characteristics which formally Foreign Citizens do not own land, but materially Foreign Citizens with instruments of agreement can control land more than Property Rights, like being immune from the law and not erased because of the social function of the land.

\section{Acknowledgment}

The author expresses his gratitude to all parties who have helped and contributed to this writing, both in the form of funding and input. Hopefully this paper can be useful both theoretically and practically for the addition and development of science especially in the field of land control by foreigners.

\section{References}

[1] Mertokusumo, S.: Mengenal Hukum Suatu Pengantar (4th ed.). Liberty, Yogyakarta (1999)

[2] Sumardjono, M. S.: Kebijakan Pertanahan Antara Regulasi dan Implementasi. Kompas, Jakarta (2005)

[3] Sumardjono, M. S.: Alternatif Kebijakan Pengaturan Hak Atas Tanah Beserta Bangunan bagi Warga Negara Asing dan Badan Hukum Asing. Kompas, Jakarta (2007)

[4] Undang-UndangRepublik Indonesia Nomor 5 Tahun 1960 tentang Peraturan Dasar Pokok-Pokok Agraria (Diundangkan pada tanggal 24 September 1960), (1960)

[5] Undang-Undang Republik Indonesia Nomor. 30 Tahun 2004 tentang Jabatan Notaris (LN. 2004. No.117, TLN No.4432), (2004)

[6] Undang-Undang Republik Indonesia Nomor. 2 Tahun 2014 tentang Perubahan Atas UU No. 30 Tahun 2004 tentang Jabatan Notaris (LN.2014.No. 3, TLN. No. 5491), (2004) 